\title{
Professionalism among Icelandic mayors: Job postings, experience and education as determinants of professionalism at the Icelandic local level
}

\author{
Eva Marín Hlynsdóttir, Assistant Professor in Political Science, University \\ of Iceland.
}

\begin{abstract}
Professionalism is thought to be synonymous with good governance, a vital component of a modern and efficient local government. Traditionally, top managers, such as American city managers, are seen as the archetype of professionalism, while municipalities ruled by executive mayors have been judged to be less professional. In Iceland, mayors are recruited largely through two processes: through hiring following nationwide job postings (managermayors) and through political appointment from within the municipal council (political mayors). An analysis of job postings for manager-mayor positions and of the level of education and experience acquired by Icelandic mayors demonstrates an increased level of professionalism. However, during interviews, manager-mayors recruited through job postings emphasised their professionalism by citing their political neutrality, while political mayors stressed their professionalism by citing their level of education. Nevertheless, there is a fundamental lack of standardisation in the qualifications required for mayoral positions in Iceland. Finally, although there is a substantial number of mayors with similar educational backgrounds in business and economics, a high turnover and a lack of mutual understanding of the experience and education required for the position indicate low levels of professionalism. Thus, although the level
\end{abstract}




\section{STJÓRNSÝSLA}

of professionalism has increased in recent years, it remains considerably lower than within the American council-manager system.

Keywords: local government; professionalism; job postings; political neutrality.

\section{Introduction}

Shortly after the Icelandic local elections in 2014, the small municipality of Svalbarðsstrandarhreppur, located near Akureyri in northern Iceland, became a headline in the national news as disputes arose over its choice of municipal administrator. The newly elected council had decided that a council member should become the municipal administrator. Many voters were unhappy and signed a petition in the hope that the council would reverse its decision. The petition's main complaint was that there should have been a job posting for the position (Jóhannesson 2014). In a neighbouring municipality, a job posting had been released for the post of municipal administrator, and the local council had received 49 applications for the position. The council members, however, decided to reject all of them, instead handpicking a former schoolmaster from the municipality for the position. This action brought forth another wave of public indignation (Ármannsson 2014a; Ármannsson 2014b). In both cases, the main complaint was that a 'professional' procedure had not been followed; the issue of whether to issue job postings when hiring municipal administrators was at the heart of the debate.

The position of the municipal administrator has its legal basis in Local Government Act no. 138/2011, of which articles 54 (appointment of a municipal administrator) and 55 (municipal administrator's area of responsibility) are most relevant to this discussion. There are no formal differences between different types of mayors with the exception that the municipal administrator has the right to vote if $\mathrm{s} /$ he is also a council member. The municipal administrator is considered to be a political mayor (pólitískur) if $\mathrm{s} / \mathrm{he}$ is also a member of the municipal council, whereas $\mathrm{s} /$ he is considered to be a managermayor (faglegur) if $\mathrm{s} /$ he is not a member of the council. A municipal administrator who is also a council member is, in international local government parlance, usually called a 'mayor', while one who is not a council member is typically called a chief executive. These forms of government are similar to those in the United States, as Icelandic political mayors are comparable to the mayors in the American mayor-council government system, and manager-mayors are equivalent to city managers in the council-manager system (Svara 1990)

As is evident from the above anecdotes, there is a tendency to see professionalism as 'good' and politics as 'bad'. Thus, Kristinsson $(2015,14)$ argued that Icelandic citizens' perception of local government corruption increases with the presence of a political mayor, while it decreases with the presence of a professional manager-mayor. If that is the case, why is it that local authorities do not always appoint manager-mayors? A possible explanation lies within our understanding of what it means to be a professional. As an example, there is an inclination towards seeing democracy and professionalism as different ends on the same continuum. Thus, professionalism is seen as technocratic 
and a threat to top-down hierarchical control by elected officials as professional norms become more important than community responsiveness (Fox 1992; Reddick \& Demir 2014). On the other end of the continuum, however, we find those who believe that professionalism entails a set of internal standards which safeguard us from politicians' arbitrary and opportunistic decision making (Fox 1992).

Previous studies conducted by Kristinsson (2001) on Icelandic local governments demonstrated a low level of professionalism for the Icelandic mayor position. Overall, Icelandic mayors had a low tenure. In general, they were not seen as professionals, as they did not need any particular expertise for the position. In addition, the mayoral position was not regarded as a real profession but more as something that 'anyone' could carry out as long as $\mathrm{s} /$ he is enthusiastic and has the best interests of the municipality at heart (91). However, at a similar point in time, Klausen and Magnier (1998a, 280-281) stated that local European chief executives were on the fast track to professionalism in the sense of shared educational background, norms and experience.

According to Mouritzen and Svara $(2002,52)$, professionalism is one of the three principles of local government, the other two being political leadership and the layman's rule. Therefore, we need professionalism in order to maintain a functioning government and to preserve democracy (Reddick \& Demir 2014). This paper addresses two research questions in analysing the level of professionalism in Icelandic local leadership:

- How is professionalism different for manager-mayors and political mayors?

- Does the use of job postings for the manager-mayor position support professionalism at the local level of Icelandic government?

There are three important points to make with regard to the position of mayor in Iceland. Firstly, it is an administrative position, as whoever holds it is the head of the local government administration. However, there are no rules as to the circumstances in which a council member should become a municipal administrator. This fact changes the picture substantially, as it is possible to have an administrator in one municipality who is a member of the municipal council and an administrator in a neighbouring municipality who is not a member of the council. This picture is further complicated by the fact that the system is not static. This stands in direct contrast to the American system, in which even though it is possible to make changes, the form of government usually stays the same over an extended period of time (Svara 1990). In the Icelandic case, municipalities may go from one form of government to another between electoral terms or even within a term. Secondly, there are no clear rules on the appointment procedures for either type of administrator. Hence, heated debates take place after each election. The third point is that the same legal framework applies to both types of mayors (Local Government Act No. 138/2011). It is, therefore, not always easy for an outsider to detect differences between the different types of municipal administrators.

This paper is divided into five parts. In the first section, it discusses the ways that professionalism can be defined and measured and describes the data upon which the present analysis is based. Next, we turn to a discussion about the selection process for 


\section{STJÓRNSÝSLA}

mayors in Iceland, analysing the justifications that are used in the selection process, with a special focus on job postings and the hiring process. The fourth part focuses on experience and education as potential determinants of professionalism. The fifth and final part discusses the research questions and offers conclusions.

\section{Professionalism at the local level}

There is no universal understanding of what professionalism means; therefore, it tends to mean "different things to different people" (Fox 1992, 2). As an example, there is much discussion about the professionalisation of politics (Berg \& Rao 2005). Research on European local leadership has shown that the importance of the layman's rule has declined, along with the amateur politicians it championed, and that professional politicians are becoming more common (Guérin \& Kerrouche 2008; Larsen 2005). The rise of the political professional (atvinnumadur) has been closely linked to the increase of executive mayors in local government (Guérin \& Kerrouche 2008). This is signalled by the critical move from emphasising the importance of the lay politician, whose primary source of income lies outside of politics, to favouring the professional politician, whose income comes mostly from within the political realm. Therefore, the professional politician can immerse him/herself in local government work, something which the lay politician is not able to do. In the case of Iceland, only the council members of Reykjavík, the capital city, are professionals in that sense. In more general terms, this definition also identifies political mayors as professionals, as they are full-time mayors whose primary income stems from their position. They belong, however, to a different category of professionals than manager-mayors.

Professionalism in public administration has been shaped by the idea that it is possible to identify elements of professionalisation against which practices may be compared (Fox 1992; Reddick \& Demir 2014). Jacobsen (2009, 64) pointed out that the minimum requirement for the existence of a profession is a well-defined level of specialisation, formal higher education geared toward that profession and the possibility of creating a career. Hekman et al. $(2009,1325)$ also argued that professionals have "dual social identities," as they identify with their institutions on the one hand and with their profession on the other. Overall, chief executives such as American city managers are expected to bring more efficiency, professionalism and stability into local government (Ammons 2008; Berg \& Rao 2005). Thus, it is possible to "see professionalism as a set of internal standards that can provide bases on which to build virtuous administration" (Fox 1992, 2). However, unlike many other types of professions, such as doctors or lawyers, the professional autonomy of city managers is highly restrained, as they are, in essence, a dependent profession in a hierarchical political relationship (Demir \& Nyhan 2008). Furthermore, Svara (1990) has argued that there is a clear conceptual link between accountability and professionalism for city managers. Thus, to safeguard their professional integrity, public administrators often turn to political neutrality.

There are several ways to define political neutrality (Mouritzen \& Svara 2002, 282). The advocates of the separation school tend to stress a polarisation of the relationship 
between politics and administration, hence the concept of the politics-administration dichotomy. They emphasise the most extreme kind of administrative neutrality, represented by an administrator who does not allow his/her work to be influenced by any interference, whether it is political, partisan or of any particular policy agenda (Demir 2009a). Expertise is the keyword, as it is the knowledge or skills of the administrator that allow him/her to make neutral decisions. This approach to neutrality has been criticised as being highly unrealistic because it does not take into account the value system of the administrator (Mouritzen \& Svara 2002), thus making him/her practically inhuman (Jacobsen 2009). These ideas also emphasise hierarchy, as they stress the importance of correct channelling and the necessity for politicians to remain uninvolved in the quotidian management of the municipalities (e.g., to refrain from giving directions to staff) (Montjoy \& Watson 1995). The interference of politicians in daily management is, therefore, seen as a potential source of corruption (Demir 2009a) which should be avoided at all costs. The administrative hierarchy provides clear chains of accountability through the administration to the manager, who is then accountable to the council (Montjoy \& Watson 1995). It has been pointed out that a strict separation may enable administrators to participate in political decision making without the possibility of being held accountable for their decisions (Aberbach, Putnam \& Rockman 1981; Bovens 2005). In his research on American city managers, Svara (1990) found that a strict separation between the two spheres can indeed result in such lack of accountability, with managers at times able to amass large amounts of power due to their experience or popularity in the community. Political accountability may be highly problematic in these cases. Problems with control may, therefore, arise from the imbalance in experience and specialised knowledge between the politician and the administrator. Even though the administration is, in theory, subservient to the political arena, in real life the power relationship can be reversed: the expert or the trained official can be a strong opponent to the politician (Mouritzen \& Svara 2002, 35-36).

As presented in the literature on American city managers, professionalism is based on the values of efficiency and merit-based hiring, and as such, the city manager is a 'symbol of rational administration in government' (Reddick \& Demir 2014, 174) who applies his/her special knowledge and expertise. Thus, education level, professional experience and participation in professional associations ${ }^{1}$ (Zhang \& Feiock 2009) are seen as important determinants of the professionalisation process.

If professionalism is defined by education, we must look for a particular type and level of education (Jacobsen 2009). Professional education helps introduce professional ethics and shared norms in municipal governance, thus reducing the chances of opportunistic behaviour (Zhang \& Feiock 2009). Different types of education bring different sets of skills and may alter the way an organisation functions. Norwegian research has shown that education is an important factor in defining how individuals in an administration behave and think (Jacobsen 2009). As an example, a majority of American city managers hold a master's degree in public administration (MPA), making the degree more or less a benchmark for the professional identification of a city manager (Reddick \& Demir 


\section{STJÓRNSÝSLA}

2014). Therefore, if the majority of Icelandic mayors hold the same degree or a similar one, that is an indicator of a higher level of professionalism.

Professional experience may be seen as the accumulation of knowledge and skills through all positions held up to the current one or through long tenure in one position (Demir \& Reddick 2012). Within the literature on American city managers, Svara (1990, 178) has identified three types of managers in relation to experience and tenure: the 'administrative generalist', the 'local appointee' and the 'careerist'. Out of these, he identified the careerist as the most common type. The main difference among these types lies in their choice of profession; whereas the careerist is specialised in local government management, the administrative generalist moves from one administrative position to another, irrespective of governmental levels or even sectors. The local appointees are individuals that are selected mainly because of local ties, without any formal training. Recent findings show that although all types still exist within the American setting, the careerist is the most common type, and many American city managers change jobs frequently on their way to their dream position (Watson \& Hassett 2004; McCabe et al. 2008). Thus, as the number of Icelandic manager-mayors who move between positions increases, the level of professionalism increases as well. However, as turnover increases, the level of professionalism decreases; this is important, because tenure is vital for the local administration's overall stability and capacity (McCabe et al. 2008).

The final determinant for professionalism for the manager-mayor position is job advertisement, which has been regularly used in Iceland for the past 100 years. As such, the postings provide valuable information on how requirements for manager-mayor positions have changed and developed, and they also provide context to the current situation. Furthermore, Anderson and Mouritzen (1998) argue that although information drawn from job postings should not be interpreted as a valid indicator of the technical requirements of the position in question, job posting analysis provides vital information about the nature of the job itself, regardless of the person who is performing it.

\section{Data collection}

This paper relies on data which was collected for a larger project on leadership at the Icelandic local level. The study relied mainly on two sources of data. Firstly, a telephone survey was conducted in December 2011. In 2011, there were 76 municipalities in Iceland. One municipality was in the process of being merged into a neighbouring municipality, and another was in the process of hiring a new manager-mayor; these two municipalities were excluded from the survey. The questionnaire was based on the questionnaires used in a study of European mayors (Bäck, Heinelt \& Magnier 2006) and in the U.Di.T.E study (Andersson \& Mouritzen 1998, 292).

The second source was semi-structured interviews. The population limit for the targeted municipalities was set at 500 inhabitants. The reason for this limit was that one of the main issues of the study was the interaction between the different types of mayors with the local administration. As very small municipalities have a highly limited administrative capacity, a cap at 500 inhabitants was deemed justifiable. In 2012, there were 
50 municipalities with more than 500 inhabitants. For the quantitative and qualitative data to be coherent, only manager-mayors and political mayors who had participated in the first round of data collection were interviewed. In the months that passed from the 2011 survey until the beginning of the interviews, six mayors had left office and were, therefore, excluded from the interviewing process. The interview sessions started in April 2012 and lasted until October 2012, at which time 12 political mayors and 32 manager-mayors had been interviewed.

For the analysis of the job postings, the database timarit.is was systematically consulted for the years 2006 and 2010. Job postings were found in Iceland's two major newspapers, Morgunbladid and Fréttabladid. Hard copies of the Morgunbladid were used to collect job postings in 2014. The majority of job postings took place in June, with a few released each year in July. Nine job postings were found in 2014, 11 were identified in 2010 and 15 were identified in 2006.

\section{The selection process of an Icelandic mayor}

It is fair to say that there is no other position at the local level that is as controversial as the position of the Icelandic mayor. The question of who should occupy the position is often a major subject of discussion before and after each local election. Parties and lists running for the municipal council frequently decide their nominee in advance, or they provide an overview of their intended process in choosing the right individual after the local elections. There are several possible ways for an individual to become an Icelandic mayor. ${ }^{2}$ Prior to an election, it has become common for political parties and lists to announce whether they intend to appoint a political mayor or hire a manager-mayor from outside the council. In the case of the political mayor, the relevant political list names its preferences for a mayor in case it wins the election. The elections, therefore, are often centred on the individual that the voters would like to see as a mayor after the election. In a similar vein, there are several ways to choose a manager-mayor. Similar to the political mayor, s/he may be the preferred choice of a particular list before the election. This is often the case when the lists running for the council would like to reemploy the sitting manager-mayor. There are, for example, cases in which all of the lists running for the council in one municipality have named the same individual as their preferred choice of manager-mayor. In selecting manager-mayors, job postings have become increasingly popular.

\subsection{The use of job postings for hiring manager-mayors}

Despite the fact that job postings have been used in the selection process for Icelandic manager-mayors for more than a century, it has only become a regular practice in the last two decades. Svara (1990) pointed out that American councils tend to hire chief executives from outside the municipality when they desire change, while they are chosen from inside the municipality during a period of consolidation. Although it is not possible to detect a firm trend in that direction in the Icelandic case, there were cases in which such reasoning was displayed in this study. Job postings provide a valuable 


\section{STJÓRNSÝSLA}

indication of the desired qualities for manager-mayors. With the growing popularity of job postings, the job description has become more elaborate in recent years. In the past, it was common for an advertisement to be very straightforward and give very little detail about the job at hand:

Municipality x needs manager-mayor, those interested should send an application to the municipality office before $\mathrm{xx}$.

By the end of the twentieth century, job postings had become richer in detail, stating the responsibilities of the position (often identical to the description provided in the Local Government Act). The selected individuals should have experience in local government and, in some rare cases, a certain level of education. Often, educational preferences were stated generally, such as 'good education' or 'relevant education', without any further explanation. Issues such as salary and housing were frequently mentioned, especially when the local council promised to help with house hunting. In some cases, local councils took unorthodox measures to find a manager-mayor, as this example from 1998 shows:

A manager-mayor position is immediately available at Öxarfjarðarhreppur. Experience in local administration is preferable. A fun and demanding position for an upbeat individual. Good salary. Individual involved must start immediately. More information from the local council leader (Morgunblaðið 1998).

This advertisement demonstrates the problem that many small rural municipalities were having in simply finding a manager-mayor. In more recent years, it has become more common to use agencies to evaluate the qualities of potential manager-mayors. The advertisements have also become more elaborate, especially concerning experience and educational preferences. However, the job postings in 2010 had one main theme: 'preferred but not necessary'. Experience in local government was preferred but not necessary; a relevant university education was preferred but not necessary. The idea seemed to be to keep all doors open.

An analysis of job postings in Morgunbladid and Fréttabladid in 2006, 2010 and 2014 revealed several commonalities in the preferred qualities of a potential manager-mayor:

- University degree or other relevant education

- Experience in managing a local municipality

- Experience in management

- Exceptional communication skills

- Interest in community development

- Leadership qualities

- Excellent written and oral communication skills

- Interest and experience in accounting

- Initiative and independent working skills

- Positive thinking

- Ability to work hard 
The most common qualities mentioned in the postings are education, experience in managing a local municipality and management in general. There are, however, no clear definitions of the type of education needed, and the phrase 'preferred but not necessary' appears regularly. This stands in direct contrast to the situation of American city managers, in which an MPA degree seems to be synonymous with 'relevant education' (Watson \& Hassett 2004; Reddick \& Demir 2014). Good communication skills and leadership qualities are also crucial. The emphasis on communication skills may partly explain the traditional overrepresentation of members of the so-called 'talking professions', such as teachers and lawyers, in local leadership positions (Steyvers \& Reynaert 2006). In addition, interest in community development is seen as an essential quality. One concern with the increase in professionalism found at the local level has been that it threatens the position of politicians as representatives of the community's identity (Fox 1992). This gives rise to a polarisation of professionalism on the one hand and the democratic community on the other. Others, such as Nalbandian (1999), have pointed out that city managers are becoming more involved in community development and that such polarisation is no longer appropriate. During the interviews with the Icelandic mayors, several political mayors raised the concern that manager-mayors were not as interested in the local community as they needed to be. The frequency with which this quality criterion was included in the job postings suggests that there is a special need to emphasise this factor. It should be pointed out that not all of these quality criteria are, however, requested at the same time. Overall, this shows that Icelandic local councils are looking for manager-mayors who can manage municipalities in an efficient and economical way. At the same time, they are often looking for someone to lead local development and initiate change and progress. From both a practical and a theoretical perspective, it may be difficult to find this mixture of management and leadership skills in the same individual (Kotter 1990).

From the two anecdotes presented at the beginning of this paper, it is obvious that there is a strong tendency among the public to equate manager-mayor job postings with open, fair and professional governance. Such ideas may stem, in part, from the introduction in 1994 of the administrative law (no. 37/1993), which promotes equity, fairness and openness in government activity. However, unlike the hiring process for all other government positions, the recruitment of manager-mayors (as well as political mayors) does not fall under any regulation or law on hiring processes. One of the main justifications for the introduction of the American council-manager form of government was to introduce the merit system in hiring in order to prevent political interference in the hiring process (Ammons 2008; Svara 1990). In contrast, there are no similar regulations for the hiring process of Icelandic manager-mayors, and there are no official quality criteria upon which the appointment should be based.

From the 32 manager-mayors interviewed, around half were hired based on a previous job posting, and a large majority had no previous connection with the municipality.

I just applied for it; I am not connected to the community in any way, and I am not political. I just applied for the position and got it. 


\section{STJÓRNSÝSLA}

Therefore, I am not a politically connected manager-mayor, as I was hired without any prior connection. (manager-mayor)

This individual was very keen to emphasise the apolitical feature of his/her position. Many of the other individuals hired following job postings used phrases such as 'just hired after a job posting' to separate themselves from those who were hired on some other basis. This shows an emphasis on political neutrality as a justification for hiring (Mouritzen \& Svara 2002). Although these descriptions depict a rather simple and straightforward process, there were other indications that it is anything but simple. On several occasions, people were contacted after being initially rejected during the hiring process: "Then they contacted me after 18 months and asked if I was still available, and I said yes" (manager-mayor). In these cases, someone else had been hired and had then left the position prematurely. In one instance, the individual was even contacted years after applying for the post. In a similar way, some individuals had applied for a position in one municipality but were offered a position in another.

It so happened that there were numerous applications. The town council did not want any of them and wanted to look for a candidate elsewhere, and I had applied for the position in a neighbouring municipality and was in the final selection. When word got out that I had not got the job, they came to me from this municipality. I was reluctant to begin with, but then I decided to give it a go. The council leader is a friend of mine, and I have a friend who lives in the neighbouring community. (manager-mayor)

This quotation sheds light on several aspects of the hiring process. First of all, receiving numerous applications does not guarantee that the council will find a candidate of whom they approve. Secondly, applying for a manager-mayor position puts the individual's name onto a sort of nationwide manager-mayor market; indeed, several of the interviewees reported having applied for a position in another municipality than the one that eventually employed them. The third and last point is related to personal acquaintances, as the individual quoted above knew the council leader, and more importantly, the council leader knew him/her. At least four of the interviewees who already had experience as manager-mayors were offered the position without having to apply: "they called me and asked me to come; I did not apply or anything" (manager-mayor). In addition, there was at least one case of an experienced manager-mayor being invited to apply for a position in another municipality as the news spread that s/he intended to leave his/her position. This suggests that previous experience within local government is a desirable quality, and those who are seen as having enjoyed success previously as manager-mayors usually have no problems in finding another position. Watson and Hassett (2004) demonstrated similar findings in their research on the career paths of American city managers, for whom experience is a valuable commodity. 
The practice of seeking potential manager-mayors is also very common among manager-mayors with backgrounds in local government (i.e., individuals who have at some point worked within the municipality's administrative system). One of the male manager-mayors with previous local administrative experience described how his career in local administration had slowly but surely driven him towards the manager-mayor position, almost as though this were the natural path for professional development in administration. Indeed, a small minority of manager-mayors can claim that entering the position was a natural career progression. Thus, the single-city careerists who are often found in the American city-manager form of government (Watson \& Hassett 2004) are rare among Icelandic manager-mayors.

The final issue to highlight relates to politics: several manager-mayors were politically affiliated with the majority in the municipal council, either by being members of the same party or by openly expressing their sympathy towards the party in question. These manager-mayors are far removed from the traditional view that professionalism requires strict political neutrality. Research has shown that such political particularism often compromises the professionalism of these managers, at least in the public's viewpoint (Demir 2009b; Protasel 1988). Most of these individuals were handpicked for the position, or they were at least strongly advised to apply for it in cases of job postings. Furthermore, political mayors and manager-mayors who were recruited through channels other than job postings interact less with the minority parties in council than with the council majority. This highlights the centrality of the Icelandic mayor's position within the local government system, as the mayor's relationship to politics seems to be closely related to the manner of his/her recruitment.

\subsection{The justification for hiring a political mayor}

Political leadership is one of the three principles of local government (Mouritzen \& Svara 2002). The way that this leadership is executed varies considerably between different forms of government. The main variation between different systems lies in the political leader's level of executive responsibility, as the role may range from being ceremonial (e.g., in Ireland) to being highly executive in nature (e.g., in France and in U.S. mayor-council cities) (Heinelt \& Hlepas 2006). Although Icelandic political mayors enjoy a high level of discretion in local decision making (Kristinsson 2015), they are not 'strong' mayors in the same sense as their American counterparts. The main reason for this lies in the fact that they are, much like the Danish borgmester, dependent on the council (Berg \& Kjær 2005), and they do not have separate powers, for example in appointing administrative staff.

Political mayors have always been a part of the Icelandic local government system. Figure 1 shows the development of the mayoral system (manager-mayors and political mayors) as well as the number of municipalities that have used the political-mayor form of government at each point in time. 
Figure 1. The number of municipalities with the mayor system (totality of manager-mayors and political mayors) and the number of political mayors, 1942$2014^{3}$

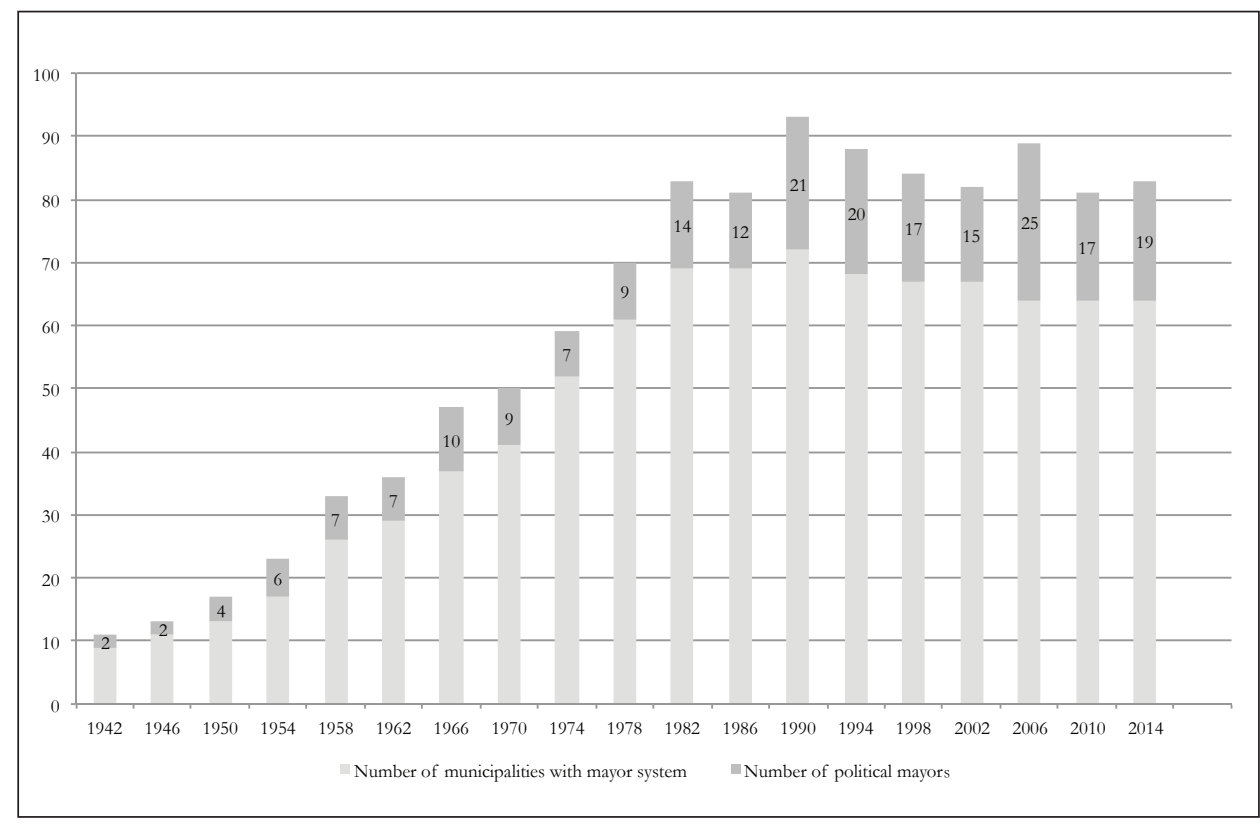

Most of the municipalities employing mayors in the initial years were towns and villages along the coastline, the remaining municipalities used the Oddviti form of government. Small rural municipalities did not begin to hire mayors until the 1990s. The number of political mayors remained stable until the 1978 elections, at which point the number decreased temporarily. The number soared again after the 1982 elections, and since 1990 the proportion of political mayors has never gone below $20 \%$. In the early years, all municipalities experimented with the mayoral system. Several municipalities have always been known for their political orientation, such as the city of Reykjavík, which has almost always employed a political mayor.

Before the 1990s, there was no obvious rule as to which municipalities employed a political mayor and which did not. As is evident from Figure 1, the number of political mayors increased in the early 1990s and remained high during the entire time period, peaking in 2006 at 25 (39\%). Analysis of the mayoral database after the 1990 local elections shows that most of the larger municipalities employed political mayors and that this trend continued until the 2010 local elections. The results from the 2010 elections were repeated in 2014, as many of the large municipalities that had previously hired political mayors began to hire manager-mayors. It remains to be seen whether this is only a short-term trend in the aftermath of the 2008 financial crisis. The trend of larger municipalities choosing politicians as their chief executives is in accordance 
with findings in other countries (Kjær 2006; Ammons 2008; Watson \& Hassett 2004). Nalbandian (1999) pointed out that charismatic mayors had become popular in America in the early 1990s, and municipalities compensated for the lack of professionalism this entailed by hiring city administrators (CAO) who were usually directly responsible to the mayors (Ammons 2008). The city administrator has no formal equivalent within the Icelandic local government system, but a possible comparison may be found within the system of the central government's ministerial assistants (Kristmundsson 2005).

The majority of political mayors are indisputably the political leaders of the council majority. Ten out of the 12 political mayors interviewed were members of one of Iceland's old, established political parties, and six of these were affiliated with the Independence Party. The majority of political mayors are career politicians who play an established role within their parties. Practically all of them had previous political experience before becoming political mayors, and the majority entered the position after the 2006 election. The fact that the majority of political mayors accumulate extensive experience before assuming their positions is in line with findings from other studies, as individuals have usually served as council members for some time before becoming mayors (Kjær 2006, 78).

The political mayors were asked why the decision had been made to appoint a politician to the role of mayor in their municipalities. The most common reason cited for appointing a political mayor was the need for efficiency in the local government.

Simply because we feel that the administration and decision making and the projects are more efficient that way because then the mayor is better connected to the political party and council, and this makes the management of the town more efficient. I think this time, both with my predecessor and now [with me], has shown that this works very well. (political mayor)

The importance of political leadership was fundamental to the mayor quoted above. The role of the professional politician is also of significance in this case, as almost all Icelandic council members are employed part time. One political mayor stressed the importance of having a professional politician in the role:

The mayor's legitimacy is entirely different when he is also a council member; the political legitimacy and the decision-making legitimacy are much greater than when the manager-mayor is directly under the council whose members make part-time management decisions. (political mayor)

None of the political mayors suggested there was a downside to having a political mayor, while they emphasised what they saw as the advantages of the practice.

The upside is that those individuals with strong visions and goals and ideas, they get so much more leverage in a small community like this one, by leading both politically and organisationally. (political mayor) 


\section{STJÓRNSÝSLA}

Overall, the political mayors stressed the importance of strong executive political leadership. This is in line with the findings of Goldsmith and Larsen (2004), who argued that when the leader of a political party has a formal leadership position, such as a mayoral position, there is room for strong-minded leaders to exploit that role. As Kristinsson (2015) pointed out, Icelandic citizens have mixed feelings about the use of political mayors. This is partly because of the general inclination to see him/her as corrupt, or at least as potentially corruptible. Hekman et al. (2009) argued that public administrators often seem to lack professional credibility, even though they are trained in a specific profession. Although many political mayors are well-educated and skilled in their field, they are often criticised for a lack of expertise or professionalism. One of the political mayors emphasised this when he stated wryly, "You do know that council members may know stuff too," thereby emphasising his view that council members are not as professionally inadequate for the office of executive mayor as some commonly believe. This point was voiced by several political mayors and politically affiliated managermayors. This is not very surprising, as these individuals are the ones most often criticised for being unprofessional. This discussion is a part of a larger debate on the concept of professionalism (Fox 1992; Reddick \& Demir 2014; Jacobsen 2009; Ammons 2008; Berg $\&$ Rao 2005). Thus, when political mayors emphasise their professionalism, they do so from the perspective that they belong to a specific profession and that this makes them professional (Hekman et al. 2009). Manager-mayors, however, see political neutrality and ethics as inseparable components of professionalism (Fox 1992).

It is fitting to finish this discussion of the selection process for political mayors with the most political of all Icelandic mayors, the mayor of the capital city of Reykjavík. The Reykjavík mayoral office is a fortress for political mayors, as there have been only a handful of cases in which a manager-mayor has occupied the position. The 2010 elections put the mayoral office in a new light. Following widespread public disillusionment and political upheaval in Iceland in the aftermath of the 2008 financial crisis, a local list called the Best Party, which was formed shortly before the elections as a means of humorous rejection of mainstream politics, won in a landslide six out of 15 open council seats, with the outspoken actor/comic Jón Gnarr as the mayoral candidate. Gnarr had no previous experience in politics and had barely finished secondary school; he was a self-made man, determined to make fun of everything and everybody, especially the established political parties. Forming a coalition with the Social Democrats, Gnarr became city mayor, and the leader of the Social Democrats became the leader of the city executive board. Gnarr was heavily criticised for his inexperience, and it was pointed out on several occasions that he was not a 'real' mayor but was letting someone else do the work that had usually been done by his predecessors. Gnarr was not an educated professional, but he was quite popular with the public, and he was indisputably a leader in the sense that he inspired and motivated people. However, his leadership was not 'executive' in the way that is usual for other political mayors. 


\section{Experience and education as determinants of professionalism}

The indicators that are most often used to determine levels of professionalism are experience and education (Zhang \& Feiock 2009). The hiring of chief executives within local government is usually based on some professional merits, such as expertise and skills (Mouritzen \& Svara 2002; Zhang \& Feiock 2009). Results from the literature on American city managers show that city managers are often 'highly educated, well paid and mobile professionals' (McCabe et al. 2008), suggesting a high level of professionalism. Although Icelandic council members, with the exception of Reykjavík city councillors, are usually only paid a small amount of money for their council work, both types of mayors are often paid handsomely. However, when it comes to their level of education and mobility, they differ substantially from their American counterparts.

\subsection{Level of experience and average tenure}

The standard way to measure experience is to look at the number of years in a position. However, it is also possible to use the number of municipalities in which an individual has served as an indicator of his/her professionalism because when an individual brings skills and knowledge from one position to another s/he develops a career at the same time.

Out of all the mayors who were active in December 2011, 31\% were new recruits, having been in office only since 2010 or later.

Table 1. Average tenure and position according to the results of the 2011 survey

\begin{tabular}{llccc}
\hline Average tenure & Gender & Mean & SD & $\mathrm{N}$ \\
\hline \multirow{3}{*}{ Political mayor } & Male & 4.6 & 3.6 & 12 \\
& Female & 3.1 & 2.1 & 5 \\
& Total & 4.2 & 3.3 & 17 \\
\hline \multirow{3}{*}{ Manager-mayor } & Male & 7.7 & 6.0 & 32 \\
& Female & 3.9 & 6.7 & 13 \\
& Total & 6.6 & 6.4 & 45 \\
\hline \multirow{3}{*}{ Total } & Male & 6.8 & 5.6 & 44 \\
& Female & 3.7 & 5.7 & 18 \\
& Total & 5.9 & 5.8 & 62 \\
\hline
\end{tabular}

As demonstrated in Table 1, there is a significant difference between the two types of local leaders; manager-mayors have an average tenure of 6.6 years, compared to 4.2 years for political mayors. Similar differences have also been detected in the literature on American city managers (Watson \& Hassett 2004). In the 2011 survey, it was found that five political mayors and 15 manager-mayors had entered office in or after 2010 . There was a notable gender imbalance, as male mayors had an average tenure of 6.8 years, compared to only 3.8 years for women. There was, however, an unusually high number of women who assumed mayoral positions in 2010; 11 out of the 22 new 
mayors were female, including two political mayors and nine manager-mayors. Female mayors comprised 29\% of the total number of mayors in the 2011 survey. The low tenure among female mayors mainly reflects the fact that they were recently hired. Therefore, when looking at the group of mayors who had been in office for more than eight years, it is unsurprising that there are only two women with more than eight years of experience and that both are manager-mayors.

Table 2. Mayors with long tenure according to the results of the 2011 survey

\begin{tabular}{lrrr}
\hline Average tenure of eight years in a position & Mean & SD & N \\
Political mayor & 10 & 1.7 & 3 \\
Manager-mayor & 13 & 6.1 & 17 \\
\hline Total & 12.5 & 5.7 & 20 \\
\hline
\end{tabular}

Table 2 demonstrates that in 2011, 20 mayors had been in office longer than eight years. Of these, 17 were manager-mayors, accounting for $38 \%$ of all manager-mayors. Among political mayors, $18 \%$ had been in office longer than eight years. Thus, the average number of years in office was lowest for political mayors while substantially higher for manager-mayors. Furthermore, a comparison with a 2001 local government study (Kristinsson 2001) shows that the number of long-serving mayors is larger now than it was before. This might indicate that although average turnover is high, a large number of manager-mayors do manage to stay in office for a very long time and are able to create a stable power base. However, and similar to the American case, long-serving mayors are more often found in smaller municipalities (under 5,000 inhabitants) than in the larger ones (Watson \& Hassett 2004).

Table 3. Number of municipalities served by mayors according to the results of the 2011 survey

\begin{tabular}{lrrrr}
\hline Number of municipalities served & 1 municipality & 2 municipalities & 3 municipalities & Total \\
Male & 26 & 13 & 5 & $44(100 \%)$ \\
Female & 17 & 1 & 0 & $18(100 \%)$ \\
\hline Total & 43 & 14 & 5 & $62(100 \%)$ \\
\hline
\end{tabular}

Kristinsson's 2001 study on Icelandic local government found that around $20 \%$ of the respondents had served in more than one municipality. As is evident from Table 3, most of the mayors who moved between municipalities were male. There were several cases of former political mayors embarking on manager-mayor careers when their political careers ended. However, there were two political mayors who had had previous experience in other municipalities. In both cases, these political mayors were individuals who had initially been hired as manager-mayors and then moved on to become council 
members in following elections. Such tendencies have been highlighted before, for example by Jónasdóttir (2011), who noted that 33\% of all mayors ${ }^{4}$ from 1986 to 2011 had served both as political mayors and manager-mayors. Of both types of mayors, $23 \%$ had served in more than one municipality. The fact that this number has not grown since Kristinsson's 2001 study suggests that serving in more than one municipality, regardless of the mayoral type, is still relatively rare. Thus, manager-mayors who are able to build careers as municipal administrators in a similar manner to American city managers remain exceptions.

\subsection{Level of education}

Kristinsson (2001) demonstrated that Icelandic mayors' professional level, as measured by education, was less developed at the local level than in the central government administration. A 2006 study revealed that among European mayors, there is an overrepresentation of professional backgrounds in brokerage and the 'talking professions', which include teachers, lawyers and public sector professionals (Steyvers \& Reynaert 2006, 43, 47). Kristinsson's (2001) findings showed similar results, although lawyers have never been as numerous in Iceland as on the European mainland. Kristinsson also found that $35 \%$ of Icelandic mayors had an educational level of high school or less and that the less educated mayors were considerably older than those with more education. Finally, manager-mayors had, on average, a much higher level of education than political mayors.

In relation to this, in an earlier study of senior officials in the central government, Kristinsson (1994) remarked that as early as $1988,93 \%$ of senior officials had obtained a university degree. The findings from the 2011 survey show that $20 \%$ of mayors do not have a university degree, compared to $35 \%$ in the 2001 study. Furthermore, the gap in the level of education between political mayors and manager-mayors has reduced gradually since 1998 (Jónasdóttir 2011). Regardless, the number of political mayors with only a high school degree $(24 \%)$ is still higher than the number of manager-mayors $(18 \%)$. The findings related to political mayors are similar to the findings of Berg and Kjær $(2005,47)$, who reported that $29 \%$ of Danish mayors did not possess a university degree. In addition, Steyvers and Reynaert (2006) conclude that it is common for up to $30 \%$ of European mayors (all of them political) to have had no university education. Similar findings were also reported by Hansen and Ejersbo (2002). Yet if education is deemed an important indicator of professionalism, then the lack of a university degree among $24 \%$ of political mayors and 18\% of manager-mayors is substantial. Moreover, if manager-mayors are to be compared to central government officials, they are still quite far from reaching the same level of educational qualification found at the central level almost three decades ago. Furthermore, it is practically unheard of for American city managers to lack formal educational credentials; and a postgraduate degree is usually the standard (Ammons 2008; Svara 1990). 
Table 4. Type of higher education obtained by mayors who participated in the 2011 survey, by gender and compared to 2001 results (Kristinsson 2001, 90)

\begin{tabular}{l|rr|r|r}
\hline $\begin{array}{l}\text { Type of higher degree } \\
\text { obtained by mayors, 2011 survey }\end{array}$ & \multicolumn{2}{|c|}{ Gender } & & \\
\hline & M & F & Total & $\begin{array}{c}\text { Educational } \\
\text { attainment in 2001 }\end{array}$ \\
\hline Educational studies & $4(12 \%)$ & $1(7 \%)$ & $5(10 \%)$ & $21 \%$ \\
Law & $4(12 \%)$ & $1(7 \%)$ & $5(10 \%)$ & $7 \%$ \\
Business/Economics & $11(32 \%)$ & $10(71 \%)$ & $21(44 \%)$ & $28 \%$ \\
Engineer/Technical Ed. & $3(9 \%)$ & 0 & $3(6 \%)$ & $26 \%$ \\
Political Science & $7(21 \%)$ & $1(7 \%)$ & $8(17 \%)$ & $14 \%$ \\
Other & $5(15 \%)$ & $1(7 \%)$ & $6(13 \%)$ & $4 \%$ \\
\hline Total & $34(100 \%)$ & $14(100 \%)$ & $48(100 \%)$ & $43(100 \%)$ \\
\hline
\end{tabular}

According to Kristinsson (2001), mayoral education was mainly concentrated in three areas: business (28\%), engineering (26\%) and education (21\%). As displayed in Table 4, the most common type of education has changed since the 2001 study. Degrees in business and economics had been obtained by $44 \%$ of mayors in 2011, and when gender differences are taken into consideration, a staggering $71 \%$ of female mayors of both types were found to have educational backgrounds in business and economics, compared to a more modest $32 \%$ of male mayors. Out of the 10 women with higher educational attainment who entered office in 2010, seven had a degree in business or economics. There is the possibility that the overall atmosphere and fiscal restraints on local government in the post-2008 era may explain this increase in mayors educated in business and economics. It is, however, difficult to explain why the difference is so strikingly gender-based. Overall, there are marginal differences in educational attainment between different types of mayors, and on the whole, the educational distribution is quite similar in both groups, except for the fact that there are no political mayors with a law degree. This suggests that in relation to education, the political mayor is becoming more professional, and in comparison to the situation in 2001, there are now only marginal differences in educational background between different types of mayors. This trend may also be an indicator of what Berg and Rao (2005) have labelled the 'professionalisation of politics', where the entrance of strong executive mayors has blurred the difference between politics and municipal administration. Others, such as Nalbandian (1999), have gone as far as to state that this trend is undermining the legitimacy of the councilmanager form of government, as increased experience and higher levels of education produce highly professional executive mayors. 


\section{Discussion}

The paper's findings indicate that the selection process of an Icelandic mayor is far from straightforward. It is possible to divide recruitment into two distinct processes, one being grounded in the principle of political leadership and the other in professionalism and the political neutrality of the manager-mayor. Thus, professional behaviour does not seem to hold the same meaning for both groups.

As an example, a professional manager-mayor is an individual who puts great emphasis on political neutrality, in accordance with the ideal type of professional municipal administrator who zealously guards his/her professional integrity. Job postings are an important tool for recruiting these types of manager-mayors. Although job postings are becoming more focused, definitions of the skills needed to be hired for a manager-mayor position remain very broad. This indicates that the development of the manager-mayor position as a profession in itself is still in its infancy. Although over $40 \%$ of manager-mayors are educated in business and economics, turnover among manager-mayors remains very high, and the number of careerists is very low. Finally, there is a gender-based difference in the recruitment process, as most of the female manager-mayors entered the position through job postings rather than through appointment processes.

The main justification for hiring a political mayor is the claim of increased efficiency, as decision-making processes become more efficient with a political mayor presiding over the administration. This justification is mainly based on a practical perspective, and although such concerns were voiced by interviewees, the political mayors placed little emphasis on the role of the political mayor as a guardian of community interests against the technocratic rationality of a public administrator. Furthermore, the analysis shows that the educational level of political mayors has become increasingly similar to that of manager-mayors. This suggests that the position of political mayor is becoming more professional and, therefore, more similar to the position of manager-mayor. This trend may be identified as an example of the professionalisation of politics.

Job postings are an important part of the selection process of manager-mayors; however, this method delivers a very specific type of manager-mayor. At the same time, quality criteria for manager-mayor positions include a high level of community involvement. This is contradictory in itself, as such a high level of community involvement is usually not a part of the agenda of a professional chief executive in local government. This paper examined the selection process of political and manager-mayors mainly from the perspective of the mayors themselves. In order to fully understand the level of professionalism at the Icelandic local level, it would also be necessary to analyse the selection process from the point of view of local councillors. Only then could we fully understand the effect of different selection processes on the professionalism of Icelandic mayors. 


\section{Acknowledgements}

The data for this study was a part of the Ph.D. project, The Icelandic mayor: A comparative analysis of political and administrative leadership roles at the Icelandic local government level. The author is grateful to the University of Iceland Research Fund for a grant awarded to the Ph.D. research project.

\section{Notes}

1 Formal professional associations for the position of local chief executives do not exist, and therefore, the variable has no relevance to this paper.

2 There are essentially three models of Icelandic local leadership: the political mayor and the manager-mayor, which will be discussed here, as well as the Oddviti model (council leader). The Oddviti model used to be the most common local government form but has become very rare and is mostly used in very small municipalities (less than 200 residents). There were 12 Oddviti leaders in Iceland during the 2011-2012 research period in comparison to around 130 in 1990. Furthermore, Oddviti leaders are often employed part time.

3 This figure is based on data collected by the author from Local Government Association handbooks and the Journal of the Local Government Association.

4 Jónasdóttir counted all the mayors who had assumed their positions during that timeframe, regardless of how short-lived their careers had been.

\section{References}

Aberbach, J. D., Putnam, R. D. and Rockman, B. A. (1981). Bureaucrats \& Politicians in Western Democracies. Cambridge: Harvard University Press.

Ammons, D. N. (2008). "City Manager and City Administrator Role Similarities and Differences: Perceptions Among Persons Who Have Served as Both," The American Review of Public Administration 38 (1), 24-40.

Andersson, L. and Mouritzen, P. E. (1998). “Technical Appendix.” in K. K. Klausen and A. Magnier (eds.), The Anonymous Leader: Appointed CEOs in Western Local Government, 285-312. Odense: Odense University Press.

Ármannsson, B. ( 2014a). "49 sóttu um stöðu sveitarstjóra.” Visiri.is. http://www.visir.is/49-sottu-umstodu-sveitarstjora/article/2014140719431.

— (2014b). "Nýráðinn sveitarstjóri ekki úr hópi umsækjenda.” Visiri.is. http://www.visir.is/ nyradinn-sveitarstjori-ekki-ur-hopi-umsaekjenda/article/2014140729710.

Bäck, H., Heinelt, H., and Magnier A. (2006). The European Mayor: Political Leaders in the Changing Context of Local Democracy. Wiesbaden: VS Verlag für Sozialwissenschaften.

Berg, R. and Kjær, U. (2005). Den danske borgmester. Odense: Syddansk Universitetsforlag.

Berg, R. and Rao, N. (2005). "Institutional Reforms in Local Government: A Comparative Framework," in R. Berg and N. Rao (eds.) Transforming Local Political Leadership, 1-14. Palgrave Macmillan.

Bovens, M. (2005). "Public Accountability.” In E. Ferlie, L. E. Lynn Jr., and C. Pollitt (eds.), The Oxford Handbook of Public Management. Oxford: Oxford University Press.

Demir, T. (2009a). "Politics and Administration: Three Schools, Three Approaches, and Three Suggestions," Administrative Theory \& Praxis 31 (4), 503-32.

- (2009b). "The Complementarity View: Exploring a Continuum in Political - Administrative Relations," Public Administration Review 69 (October), 876-88. doi:10.1111/j.1540-6210.2009.02037.x.

Demir, T. and Nyhan R. C. (2008). "The Politics-Administration Dichotomy: An Empirical Search for Correspondence between Theory and Practice," Public Administration Review (68), 81-96. doi:10.1111/ j.1540-6210.2007.00839.x. 
Demir, T, and Reddick, C. G., (2012). "Understanding Shared Roles in Policy and Administration: An Empirical Study of Council-Manager Relations" Public Administration Review 72 (4), 526-36.

Fox, C. J. (1992). “What do We Mean When We Say 'Professionalism?’ A Language Usage Analysis for Public Administration," Rationality and Society 22 (1), 1-17.

Goldsmith, M. and Larsen, H. O. (2004). “Local Political Leadership: Nordic Style," International Journal of Urban and Regional Research 28 (1), 121-33.

Guérin, É. and Kerrouche É. (2008). "From Amateurs to Professionals: The Changing Face of Local Elected Representatives in Europe," Local Government Studies 34 (2), 179-201.

Hansen, K. H. and Ejersbo N. (2002). "The Relationship between Politicians and Administrators - a Logic of Disharmony," Public Administration 80 (4), 733-50.

Heinelt, H. and Hlepas, N-K. (2006). "Typologies of Local Government Systems" in H. Bäck, H. Heinelt, and A. Magnier (eds.), The European Mayor: Political Leaders in the Changing Context of Local Democracy, 21-42. Wiesbaden: VS Verlag für Sozialwissenschaften.

Hekman, D. R., Steensma, H. K., Bigley G. A. and Hereford J. F. (2009). "Effects of Organizational and Professional Identification on the Relationship Between Administrators' Social Influence and Professional Employees' Adoption of New Work Behavior," The Journal of Applied Psychology 94 (5), 1325-35. doi:10.1037/a0015315.

Jacobsen, D. I. (2009). Administrasjonens makt-om forbolded mellom politik og administrasjon. 4th ed. Bergen: Fagbokforlaget.

Jóhannesson, P. (2014). "Valdarán af sverustu gerð." Akureyri vikublad, no. 7th August. http://www. akureyri.net/frettir/2014/08/07/valdaran-af-sverustu-gerd/.

Jónasdóttir, K. Ó. (2011). "Framkvæmdastjórar sveitarfélaga: Litið til menntunar, pólitískrar pátttöku, kyns, búsetu og starfsaldurs peirra sem störfuðu á árunum 1986-2011.” MPA thesis University of Iceland.

Kjær, U. (2006). “The Mayor's Political Career,” in H. Bäck, H. Heinelt and A. Magnier (eds.), The European Mayor: Political Leaders in the Changing Context of Local Democracy, 75-98. Wiesbaden: VS Verlag für Sozialwissenschaften.

Klausen, K. K. and Magnier, A. (1998). "The New Mandarins of Western Local Governments- Contours of a New Professional Identity?" in K. K. Klausen and A. Magnier (eds.), The Anonymous Leader: Appointed CEOs in Western Local Government, 265-84. Odense: Odense University Press.

Kotter, J. (1990). Force for Change: How Leadership Differs from Management. New York: The Free Press.

Kristinsson, G. H. (1994). Embattismenn og stjórnmálamenn: Skipulag og vinnubrögd i islenskeri stjórnsýshu. Reykjavík: Heimskringla.

- (2001). Staðbundin stjórnmál: Markmið og árangur sveitarfélaga. Reykjavík: Háskólaútgáfan. -(2015). "Political Control and Perceptions of Corruption in Icelandic Local Government," Icelandic Review of Politics \& Administration 11 (1), 1-18. http://www.irpa.is/article/view/a.2014.10.1.1/ pdf.

Kristmundsson, Ó. H. 2005. “Bakgrunnur aðstoðarmanna ráðherra: Próun 1971-2005,” Icelandic Review of Politics \& Administration 1 (1), 63-80.

Larsen, H. O. (2005). “Transforming Political Leadership: Models, Trends and Reforms," in R. Berg and N. Raon, Transforming Local Political Leadership,195-211. Palgrave Macmillan.

McCabe, B. C., Richard C. F., Clingermayer J. C., and Stream C. (2008). "Turnover Among City Managers: The Role of Political and Economic Change," Public Administration Review 68 (2), 380-86. http:// onlinelibrary.wiley.com/doi/10.1111/j.1540-6210.2007.00869.x/full.

Montjoy, R. S. and Watson D. J. (1995). "A Case of Reinterpreting Dichotomy of Politics and Administration as a Professional Standard in Council-Manager Government," Public Administration Review 55 (3), 231-239.

Morgunblaðið (1998). “Sveitarstjóri.” Morgunblaðið, 7 June. 
Mouritzen, P. E. and Svara, J. H. (2002). Leadership at the Apex: Politicians and Administrators in Western Local Governments. Pittsburgh: Pittsburgh University Press.

Nalbandian, J. (1999). "Facilitating Community, Enabling Democracy: New Roles for Local Government Managers," Public Administration Review 59 (3), 187-97.

Protasel, G. J. (1988). “Abandonments of the Council-Manager Plan: A New Institutionlist Perspective," Public Administration Review 48 (4), 807-12.

Reddick, C. G. and Demir T. (2014). "Professional Identification and City Managers: An Analysis of a National Survey," International Journal of Public Administration 37 (3), 174-82. doi:10.1080/01900692 .2013 .809586 .

Steyvers, K. and Reynaert H. (2006). "'From the Few are Chosen the Few...' On Social Background of European Mayors," in H. Bäck, H. Heinelt, and A. Magnier (eds.), The European Mayor: Political Leaders in the Changing Context of Local Democracy, 43-74. Wiesbaden: VS Verlag für Sozialwissenschaften.

Svara, J. H. (1990). Official Leadership in the City: Patterns of Conflict and Cooperation. Oxford University Press.

Watson, D. J. and Hassett, W. L. (2004). "Career Paths of City Managers in America's Largest CouncilManager Cities," Public Administration Review 64 (2), 192-99. doi:10.1111/j.1540-6210.2004.00360.x.

Zhang, Y. and Feiock, R. C. (2009). "City Managers' Policy Leadership in Council-Manager Cities," Journal of Public Administration Research and Theory 20, 461-76. 